\title{
Editorial
}

\section{Exclusion and Belonging in Urban Public and Quasi-Public Space}

\author{
Peer Smets ${ }^{*}, 1, \S$ and Paul Watt ${ }^{*}, 2, \S$ \\ ${ }^{I}$ Department of Sociology, VU University Amsterdam, The Netherlands \\ ${ }^{2}$ Department of Geography, Environment \& Development Studies, Birkbeck, University of London, UK
}

\section{PUBLIC AND QUASI-PUBLIC SPACE}

Public space - which comprises streets and sidewalks, parks and plazas - is one of the justly celebrated aspects of cities. If cities are rich arenas of social diversity and crucibles of civic participation, it is their public spaces which facilitate the coming together of diverse populations since there is 'a presumption that within these spaces we will, necessarily, encounter "others" in all their many differences" [1]. The meanings and functions of public space have increasingly become a matter of debate for urbanists, not least in relation to what, if anything, public space might mean under conditions of $21^{\text {st }}$ century 'splintering urbanism' [2]. While urbanists such as Amin and Thrift [3] are sceptical regarding the democratic potential of public space seeing it merely as offering places of sociability and tolerance, Staeheli and Mitchell [4] put forward the view that 'being present in public space - making claims to and becoming visible in the streets, sidewalks, squares and parks of the city - is a vital, necessary step in making claims on the public and as part of the public' (p. xiv).

Running alongside such debates over the political potential of urban public space is growing anxiety over matters of exclusion and belonging. From Mike Davis' City of Quartz [5] to Stephen Graham's Cities Under Siege [6], the diminution of urban public space - via the proliferation of privatized zones of hyper-consumption alongside heightened mechanisms of paranoid surveillance - has become a staple of the urban studies' literature. Is public space genuinely open to the public as a whole, who thereby have a right to belong in it, or is public space demarcated and controlled so that some groups have greater access rights than others who are deemed not to belong?

Sanitizing a city's public spaces to make them appeal to tourists and high-spending residents has become an allimportant aspect of urban neoliberalization strategies. One prominent example can be seen in the staging of urban

\footnotetext{
*Address correspondence to these authors at the (Peer Smets) VU University Amsterdam, De Boelelaan 1081, 10181 HV Amsterdam, The Netherlands; Tel: 003120598 6742; Fax: 003120598 6810; E-mail: p.g.s.m.smets@vu.nl; (Paul Watt) Birkbeck, University of London, Department of Geography, Environment and Development Studies, 26 Malet Street, London WC1E 7HX, UK; Tel: 0044203073 8371;

E mail: p.watt@bbk.ac.uk

${ }^{\S}$ Guest Editors
}

sporting, cultural, and political 'mega-events' such as the Olympic Games and the World Cup. Cities stage such megaevents as a means to boost their standing in the global city hierarchy. Alongside the hoped-for tourist influx, megaevents' high mass media profile means that the host city is de facto on display to rest of the world as millions tune into watch the football games and athletics on their TV screens. City politicians are only too well aware of the potential impact of these media screenings on the host city's global image and tourist economy, and hence make strenuous efforts to present their city in the best light possible. This involves pursuing strategies of 'beautification' (tidying up) and 'securitization' (clamping down on disorder or perceived potential disorder) vis-à-vis public space [7, 8]. Those social groups which are deemed to constitute the 'dirty' and 'disorderly' aspects of urban life, notably the homeless, can often have their access to public space severely curtailed during the staging of the events. This happened during both the 2010 Vancouver Winter Olympic Games and the 2012 London Summer Olympic Games as low-income and homeless youth were subject to greater policing powers and scrutiny, while simultaneously the streets and public thoroughfares were tidied up and made presentable for visiting tourists $[9,10]$.

Threats to public space are often, rightly, linked to privatization processes which increasingly occur via largescale urban regeneration and downtown renewal schemes, as documented by Staeheli and Mitchell [4] in the case of US cities and Minton [11] in relation to UK cities. In the contemporary neoliberal city, downtowns and their adjacent 'zones of transition' are being remade and in many cases rebranded by the presence of corporate shopping malls and centers, casinos and gated residential communities. These 'quasi-public' or 'pseudo-public' spaces have a public appearance, but they are in reality spaces which are heavily controlled and monitored via private security guards and banks of CCTV cameras whose function is to control and/or exclude certain 'undesirable' groups - typically low-income youths, the homeless and non-consumers. If streets, plazas and parks bring urban 'others' haphazardly together in the same space, 'shopping centres epitomise the construction of sanitised consumption environments predicated on eliminating the unpredictability and dangerousness of urban interactions' [12]. Issues of exclusion and not-belonging are thus central to how these quasi-public urban spaces operate, although by no means all researchers subscribe to the notion that shopping malls, for example, necessarily mean the 
erosion of public space but rather that users develop new conceptions of what public space means [13].

One further important aspect of the relationship between exclusion, belonging and public and quasi-public space is how increasing social diversity within cities can potentially lead to competing claims over the use and identity of such spaces $[14,15]$. Arguably, in order for a livable and pleasant atmosphere in public space, it is important that users of different ethnic origins, class backgrounds, gender and age have a common or partly linked sense of belonging. Such belonging is determined by factors such as the physical environment and place images and symbols, as well as feelings of community [16]. People employ strategies to obtain a sense of belonging linked to public space and quasipublic space, and these strategies often go together with mechanisms of inclusion and exclusion.

Walzer proposes the use of a public space continuum with at one end single-minded space and at the other end open-minded space. Single-minded space is designed for one purpose only and used by single-minded citizens. Once people do not want to mingle with different persons, a single-minded space - which often resembles private space could be very convenient. Open-minded space is designed for different foreseen and unforeseeable uses, and its users employ different activities, but may have interest in things they don't do. In other words, open-minded spaces offer alternative kinds of activities and encounters [17].

Space - whether having open, closed or controlled characteristics - has barriers that influence spatial behavior: the physical appearance of the built environment; the mental space or the perception of space. Here, codes and signs which are related to fears and perceptions of activities in that space prevent people from entering these spaces. Moreover, legal prohibitions on entering places or constructing formal barriers can be caused by social control. This can be a 'combination of formalized rules and regulations, informal codes and signs, and fears and desires [that] control our spatial behaviour and alert us to the limitations on our access' [18]. Once people feel at home in a certain place it may include similar people and exclude different ones [19].

\section{OVERVIEW OF THE PAPERS}

Felicity Chan analyzes tensions and conflicts in everyday encounters and negotiations in three multi-ethnic neighborhoods with different income levels in Los Angeles: a low-income and densely populated neighborhood, a mixedincome neighborhood with multiple environments, and an affluent and exclusive enclave. She pays attention to intercultural interaction from the viewpoint of the different ethnic groups and how local senses of belonging develop in the neighborhood where they reside. On the basis of these insights, she discusses processes of boundary guarding and boundary crossing.

In their paper, Kees Boersma, Hannah Langen and Peer Smets focus on a multi-ethnic neighborhood in Amsterdam East in the contexts of gentrification, studentification and organization theory. They discuss how the student-led centre 'Studio K' aims to create a space where all neighborhood residents would feel at home. However, in practise the students deal mainly with look-a-likes and tend to refrain from developing contact with residents of different ethnic origin. Intentions of establishing interethnic contacts have failed and an exclusionary quasi-public island is created for students and middle-class residents.

Sara Martucci examines gentrification in relation to the use of public space in Williamsburg, a former working-class neighborhood in Brooklyn, New York City. She describes the annual street closure event called 'Williamsburg Walks' in which a traffic free road encourages citizens to rethink the celebration and branding of the neighborhood. Merchants, residents and event organizers rethink the use of the street during these events. Martucci shows how gentrifiers increasingly dominate the event and aim at branding the neighborhood for the better off and in so doing exclude longterm residents. Contrary to Boersma et al., Martucci uses a broader definition of public space, one which also includes cafés and restaurants.

The three articles presented above focus on Western cities. Anna Zhelnina, by contrast, looks into post-socialist developments of urban public space in St. Petersburg, Russia. Here a friction occurs between 'the museum city', related to the UNESCO World Heritage status, and 'the people's city', which refers to a new Western European use of public spaces, for example parks and streets. Zhelnina shows how it is difficult for citizens to use public space, but the government also faces difficulties with their new role.

Finally, Aya Nassar considers the public sphere - as a political concept and a 'Western' normative ideal of freedom and inclusion - which appears to have an exclusive nature. To illustrate this Nassar describes how the Al-Azhar park in Cairo, which was initially meant for all classes, is increasingly being taken over by the middle and upper classes. She pays attention to the politics of inclusion and exclusion, the nature of power relations, social practices, surveillance and the landscape in the park and its surroundings.

This edited collection shows how local public and quasipublic space is determined by different space-time configurations in which open-minded space can often turn into single-minded space where users distinguish themselves from those who differ from them. Here processes of beautification and securitization play an important role. The main themes of the papers include a focus on mechanisms of inclusion and exclusion (Martucci) in combination with senses of belonging (Chan, Boersma et al., Zhelnina, Nassar). The papers collectively offer a rich sociological insight into how public and quasi-public spaces are both defined and used in diverse cities around the globe.

\section{REFERENCES}

[1] Bottomley A, Moore N. From walls to membranes: fortress polis and the governance of urban public space in 21 st century Britain. Law Critiq 2007; 18:171-206.

[2] Graham S, Marvin S. Splintering Urbanism. London: Routledge 2001.

[3] Amin A, Thrift N. Cities: Reimagining the Urban. Cambridge: Polity 2002.

[4] Staeheli LA, Mitchell D. The People's Property? Power, politics and the public. New York: Routledge 2008.

[5] Davis M. City of Quartz. London: Verso 1990.

[6] Graham S. Cities under Siege: The New Military Urbanism. London: Verso 2010. 
[7] COHRE (Centre on Housing Rights and Evictions). One World, Whose Dream? Housing Rights Violations and the Beijing Olympic Games. Geneva: COHRE 2008.

[8] Fussey P, Coafee J, Armstrong G, Hobbs D. The regeneration Games: purity and security in the Olympic city. British Journal of Sociology 2012; 63(2): 260-284.

[9] Kennelly J, Watt P. Sanitizing public space in Olympic host cities: the spatial experiences of marginalized youth in 2010 Vancouver and 2012 London. Sociology 2011; 45(5): 765-81.

[10] Kennelly J, Watt P. Restricting the public in public space: the London 2012 Olympic Games, hyper-securitization and marginalized youth, Sociological Research Online 2013; 18(2) Available from: http://www.socresonline.org.uk/18/2/19.html

[11] Minton A. Ground Control. Fear and happiness in the $21^{\text {st }}$ century city. London: Penguin Books 2012.

[12] Flint J. Surveillance and exclusion practices in the governance of access to shopping centres on periphery estates in the UK. Surv Soc 2006; 4(1/2): 52-68.
[13] Tyndall A. 'It's a public, I reckon': publicness and a suburban shopping mall in Sydney's Southwest. Geographical Research 2010; 48(2):123-36.

[14] Smets P. Community development in contemporary ethnic plurifom neighbourhoods: a critical look at social mixing. Comm Develop J 2011; 46(S2): ii15-ii32.

[15] Smets P, den Uyl M. The complex role of ethnicity in urban mixing. A study of two deprived neighbourhoods in Amsterdam. Urban Stud 2008; 45(7): 1439-60.

[16] Duyvendak JW. The Politics of Home. Belonging and nostalgia in Western Europe and the United States. London: Palgrave MacMillan 2011.

[17] Walzer M. Pleasure and costs of urbanity. In: Kasinitz P, Ed. Metropolis. Center and Symbol of our Times. Hampshire, London: MacMillan.

[18] Madanipour A. Social exclusion and space. In: LeGates RT, Stout F. Eds. The City Reader. New York: Routledge 2003.

[19] Smets P, Kreuk N. Together or separate in the neighbourhood? Contacts between natives and Turks in Amsterdam. Open Urban Stud J 2008; 1: 35-47.

(C) Smets and Watt; Licensee Bentham Open.

This is an open access article licensed under the terms of the Creative Commons Attribution Non-Commercial License (http://creativecommons.org/licenses/by-nc/3.0/) which permits unrestricted, non-commercial use, distribution and reproduction in any medium, provided the work is properly cited. 